Illinois State University

ISU ReD: Research and eData

$10-2020$

\title{
It Takes a Village: Populating the Institutional Repository with Performing Arts Content
}

Anne Shelley

Illinois State University, aeshell@ilstu.edu

Follow this and additional works at: https://ir.library.illinoisstate.edu/fpml

Part of the Library and Information Science Commons

\section{Recommended Citation}

Shelley, Anne, "It Takes a Village: Populating the Institutional Repository with Performing Arts Content" (2020). Faculty and Staff Publications - Milner Library. 117.

https://ir.library.illinoisstate.edu/fpml/117

This Article is brought to you for free and open access by the Milner Library at ISU ReD: Research and eData. It has been accepted for inclusion in Faculty and Staff Publications - Milner Library by an authorized administrator of ISU ReD: Research and eData. For more information, please contact ISUReD@ilstu.edu. 
It Takes a Village: Populating the Institutional Repository with Performing Arts Content

\begin{abstract}
:
Managing an institutional repository is not a project in its own right: rather, it is an operational service that involves conversations with faculty, students, and other content providers. However, once those stakeholders decide that the repository is a good, stable, discoverable home for their work, there are projects involved in populating the repository. This article presents a case study of how the author, a music librarian and institutional repository manager at Illinois State University, approached adding thousands of items from the Wonsook Kim College of Fine Arts into the institutional repository, ISU ReD: Research and eData.
\end{abstract}

\author{
Anne Shelley \\ Illinois State University
}

Keywords: Institutional repository, Project management, Scholarly communication 


\section{Introduction}

In 2017, I took on the position of scholarly communication librarian at an institution where I had been the music librarian for five years. While I am still the music librarian for the time being, I have assumed new responsibilities. I coordinate programming and outreach initiatives about resources, tools, and methods related to open access publishing, open educational resources, and digital scholarship. I help faculty and graduate students determine legitimacy and quality of journals to which they might submit a manuscript, and I assist faculty with citation analyses to help determine their scholarly impact. I also manage our institutional repository, ISU ReD: Research and eData. ${ }^{1}$ When I started this new position, there had not been much content in ISU ReD that represented the hundreds of performances, publications, and exhibitions that take place each year in the Wonsook Kim College of Fine Arts at Illinois State University. Being in this dual role seemed like an excellent opportunity to enhance the presence of fine and performing arts materials in ISU ReD. While managing the repository is truly an ongoing service that involves both outreach to content providers as well as stewardship of their materials, creating many of the collections in the repository requires oversight of and decisions regarding managing a timeline, item inventory, metadata fields, reformatting specifications, batch uploading, promotion, and human and financial resources to accomplish these tasks. In this article, I will discuss the project management principles involved in creating more ISU ReD collections that feature works in music, art, dance, and theater.

ISU ReD launched in 2013. We use the hosted repository service Digital Commons, which is run by the company bepress. To date, ISU ReD contains about 9,150 items and has seen a total of 670,000 downloads. ISU ReD hosts copies of pre-published journal articles, book chapters, and reviews. It also holds student theses and dissertations from 2013 to present, as well as other student works that have been reviewed and endorsed by a faculty member. Juried presentations by both faculty and students are also included. Digital Commons also allows the library to host original publications; it has behind-the-scenes tools for peer review and communication between editors, reviewers, and authors. We currently publish three journals in the fields of biomathematics, STEM teaching and learning, and teaching and learning in communication sciences and disorders. ISU ReD also hosts an open access book series, published by an imprint of the Illinois State University Publications Unit. In addition to storing, sharing, and providing persistent access to this content, the library maintains a membership with CrossRef and registers digital object identifiers (DOIs) for any original content that is published in ISU ReD.

The Wonsook Kim College of Fine Arts houses three Schools-Art, Music, and Theatre and Dance - as well as a Program in Arts Technology. Collectively, the College presents hundreds of music and dance performances, exhibitions, and theater productions each year. Two subject librarians serve as liaisons to the College, one for music and the other for the remaining schools and program.

\footnotetext{
${ }^{1}$ Milner Library, Illinois State University, “ISU ReD: Research and eData," accessed February 10, 2020, https://ir.library.illinoisstate.edu/.
} 
Illinois State University was originally founded as a teacher's college and is the oldest public institution in the state of Illinois. It has a Carnegie classification of Doctoral-High Research Activity. In a typical fall semester, enrollment is around 20,000, with the vast majority being undergraduate students.

\section{Motivations and Approach}

To those reading this article, it is likely not news that scholarly communication is different for the fine and performing arts compared to other disciplines. While many faculty in music, art, dance, and theatre publish in traditional venues like journals, they are also accustomed to a different peer review system than the sciences and humanities. Quality and meaning in the performing and fine arts are measured through live performances and gallery shows, competitions, reviews, residencies, and recordings. A 2010 study from UC Berkeley's Center for Studies in Higher Education explored scholarly communication activities and needs of faculty in seven broad disciplines, music being one of them. The report emphasizes the wide range of accepted "publication" venues in music, including "monographs, journal articles, book chapters, encyclopedia articles, conference proceedings, critical editions of musical manuscripts for study or performance, reviews, liner and program notes, discographies, CDs, multimedia websites, scores, live performances, DVDs/videos of performances, recordings (albums or single tracks), and software (which can represent new computer-based instruments or protocols for musical performance or composition)." 2 There are copyright complexities with making fine and performing arts materials available open access. A 2014 report commissioned by the College Art Association explores problems inherent in the current "permissions culture" of visual arts fields, where artists and scholars are more inclined to seek authorization to use copyrighted material as opposed to conducting their own fair use analysis. ${ }^{3}$ Even when the underlying work is in the public domain, there is not a consensus among major art museums on an ideal approach for sharing images online, according to a 2013 CLIR Report. ${ }^{4}$ And even if there were not such complex intellectual property considerations, there are definitely technical ones. Institutional repositories were developed to house and make available text-based works - specifically, PDF copies of peer-reviewed literature authored by faculty, with the expectation that faculty would upload their works themselves. ${ }^{5}$ Most repositories can now host a variety of file types, but how

\footnotetext{
${ }^{2}$ Diane Harley, Sophia Krzys Acord, Sarah Earl-Novell, Shannon Lawrence, and C. Judson King, "Assessing the Future of Landscape of Scholarly Communication: An Exploration of Faculty Values and Needs in Seven Disciplines," (Berkeley, CA: The Center for Studies in Higher Education, 2010), accessed May 29, 2020, https://escholarship.org/uc/item/15x7385g\#, 507.

${ }^{3}$ Patricia Aufderheide, Peter Jaszi, Bryan Bello, and Tijana Milosevic, "Copyright, Permissions, and Fair Use among Visual Artists and the Academic and Museum Visual Arts Communities: An Issues Report," accessed May 29, 2020, https://www.collegeart.org/pdf/FairUseIssuesReport.pdf, 7.

${ }^{4}$ Kristin Kelly, "Images of Works of Art in Museum Collections: The Experience of Open Access. A Study of 11 Museums," CLIR Publication No. 157, Washington, D.C.: Council on Library and Information Resources, 2013, accessed May 29, 2020, https://www.clir.org/pubs/reports/pub157/, 1.

${ }^{5}$ Soo Young Rieh, Karen Markey, Elizabeth Yakel, Beth St. Jean, and Jihyun Kim, "Perceived Values and Benefits of Institutional Repositories: A Perspective of Digital Curation," Paper presented at DigCCurr 2007: An International Symposium in Digital Curation, Chapel Hill, NC, April 2007, https://ils.unc.edu/digccurr2007/program.html.The authors presented the results of this empirical study at a 2007
} 
those files display to users is not always ideal. Despite these challenges, the scholarly and creative activity that happens among our fine and performing arts faculty and students is constant and it is important, and the repository is a tool that libraries can use and are using to help document and preserve their work.

I had several goals for adding more fine and performing arts content to the repository. Creating a digital copy and adding it to ISU ReD are both steps toward preserving the publication. Many of the programs that we have added in the past year were collected from the bottom drawer of filing cabinets in faculty offices. In addition, ISU ReD provides a stable URL for each item, so we feel confident that links to content will not break. Adding fine arts content to ISU ReD helps make it more visible. Instead of being on a shelf or in a filing cabinet, information about concerts, exhibitions, faculty activities, and student research are now searchable on the open web. I am also hopeful that these collections will be helpful for Wonsook Kim College of Fine Arts alumni. Graduates can refer back to programs they performed on or attended as students. If they choose to include their thesis or other work in ISU ReD, they can count on the link to their work being reliably available if they choose to include it on their $\mathrm{CV}$ or an application for a job, grant, or residency.

In order to get permission to add fine and performing arts content to the repository and get access to the materials themselves, I worked with certain stakeholders in the Wonsook Kim College of Fine Arts and in Milner Library. I thought about the relationships I had established as the music librarian and who I might want to approach first. I have collaborated with the assistant dean in the College, particularly regarding outreach initiatives to students and faculty. I thought she would be interested in the potential visibility that the College might enjoy from having its materials digitized and made open access in the repository. In addition, my librarian colleague who is the liaison for art, theatre, and dance is well-connected with those faculty and students, as well as staff in our University Galleries. I set up an initial meeting with these colleagues, in which we discussed what types of content would be good to start with, based on availability and accessibility of materials, format, value of the materials to a wider community, and potential copyright restrictions. We decided to begin by developing collections of materials that are managed and published at the department level, such as programs from concerts and festivals, faculty newsletters, and schedules for gallery shows.

While several repository collections have been created through this collaboration to date, I will focus on only three in this article: programs of School of Music performances, materials documenting the history of the Red Note New Music Festival, and programs of the Illinois Shakespeare Festival.

symposium on digital curation. The study surveyed academic library directors on the benefits of an institutional repository, and respondents rated "capturing the intellectual capital of your institutions" as the most important benefit (https://ils.unc.edu/digccurr2007/papers/rieh_paper_6-2.pdf, p. 3). 


\section{Changes in Philosophy Regarding Institutional Repositories}

Institutional repositories started becoming more common in the early 2000s. Since that time, there has been a shift in thinking about the purpose of a repository and philosophies about what content should be included. When institutional repositories first started, there was a focus on encouraging faculty to self-submit copies of their publications and optimism that they would do so. A 2002 SPARC position paper advocating for institutional repositories describes them as "a digital archive of the intellectual product created by the faculty, research staff, and students of an institution and accessible to end users both within and outside of the institution, with few if any barriers to access." ${ }^{16}$ However, even with many universities enacting open access policies that mandated or encouraged faculty to deposit a version of their published work in the IR, participation rates have not been what librarians and open access advocates had hoped for. In their 2007 study of faculty participation in Cornell University's implementation of DSpace, Davis and Connolly reported that the repository was "largely underpopulated and underused by its faculty." "7 In 2010, Cullen and Chawner discovered that only six percent of surveyed academics in New Zealand "used the repository in any meaningful way." ${ }^{8}$ In a much more recent study, Lambaria interviewed faculty in the fine and performing arts about their perception of institutional repositories. She identified concerns related to retaining ownership of the work, copyright, collaborative works, and investing time in depositing materials. ${ }^{9}$ Goals of having a green open access model help in bringing down journal subscription costs and bring equity to access to research have not materialized.

Clifford Lynch, the director of the Coalition for Networked Information, even as early as 2003, took a broader view of the purpose of repositories and left the door open for what types of content might live in an IR. In a widely-cited 2003 ARL Bulletin, Lynch argued that a repository is "a set of services that a university offers to the members of its community for the management and dissemination of digital materials created by the institution and its community members." ${ }^{10} \mathrm{He}$ doesn't say the word "librarian" in this quote, but he is implying that there needs to be people providing repository services to the university community, encouraging

\footnotetext{
${ }^{6}$ Raym Crow, "The Case for Institutional Repositories: A SPARC Position Paper" (Washington, D.C.: Scholarly Publishing \& Academic Resources Coalition, 2002), accessed February 10, 2020, https://ils.unc.edu/courses/2014_fall/inls690_109/Readings/Crow2002-

CaseforInstitutionalRepositoriesSPARCPaper.pdf, 16.

${ }^{7}$ Philip M. Davis, and Matthew J. L. Connolly, "Institutional Repositories: Evaluating the Reasons for Non-use of Cornell University's Installation of DSpace,” D-Lib Magazine 13, no. 3/4 (2007), accessed May 29, 2020, http://www.dlib.org/dlib/march07/davis/03davis.html, conclusion.

${ }^{8}$ Rowena Cullen, and Brenda Chawner, "Institutional Repositories: Assessing Their Value to the Academic Community," Performance Measurement and Metrics 11, no. 2 (2010): 141.

${ }^{9}$ Kate Lambaria, "Considering Creative Activity in Institutional Repositories: An Exploration of Faculty

Perceptions," Journal of Librarianship and Scholarly Communication 8, no. 1 (2020): p.eP2312, http://doi.org/10.7710/2162-3309.2312.

${ }^{10}$ Clifford Lynch, "Institutional Repositories: Essential Infrastructure for Scholarship in the Digital Age," ARL Bimonthly Report 226 (February 2003): 2, accessed February 10, 2020, https://www.cni.org/wpcontent/uploads/2003/02/arl-br-226-Lynch-IRs-2003.pdf.
} 
participation and providing assistance in using and understanding the system, rather than a university just offering the technology and assuming faculty will engage with it.

Much more recently, in 2016, Lynch was interviewed by Richard Poynder, a writer who follows open access developments. In this Q\&A, Lynch provided his current vision on what we should be doing with IRs, saying they should not be used to "disrupt the existing scholarly publishing system, but to allow it to be expanded and diversified by providing access and stewardship for material that mainly falls outside of the traditional scholarly publishing system as it exists today - both material created by faculty and material created by the institution, or departments or other groups within it." 11 In a presentation at the 2016 Annual NASIG Conference, T. Scott Plutchak examines the similarities and differences of Crow's and Lynch's philosophies on the purpose and scope of institutional repositories. Plutchak suggests that libraries take an approach to IR management that "enables institutional repository managers to focus on material that is outside the formal publishing program. There is so much happening at all of our institutions that would be valuable to share. The institutional repository is a fabulous vehicle for doing that."12

So it is in this more recent mindset of Lynch and that of Plutchak and Moore that I have approached adding arts content to our repository. A handful of faculty publications are represented, but most of the content we have focused on documents the wider operations and events of our College of Fine Arts, namely concert programs, festival programs, theses and dissertations, and newsletters.

\section{Components and Phases of Digital Projects ${ }^{13}$}

While decisions made on details such as file formats, project timeline, copyright status, and metadata will vary from project to project, most digital or institutional repository projects can be broken down into three defined phases.

The Pre-production phase involves planning, making decisions about project details, and finalizing the roles of the project team and content providers. Any copyright concerns should be addressed at this point or earlier and it may be wise to consult with library administration, a campus copyright officer, and/or University counsel before proceeding with the project. Is the material public domain, or under copyright and permission is required, a combination of both, or does the library make a fair use case for creating the collection? The size and scope of the collection is determined, ideally by having a finalized inventory of the items, and/or an estimate

\footnotetext{
${ }^{11}$ Richard Poynder, "Q\&A with CNI's Clifford Lynch: Time to Re-think the Institutional Repository?” last modified September 22, 2016, https://richardpoynder.co.uk/Clifford_Lynch.pdf, 5.

${ }^{12}$ Plutchak, T. Scott (speaker), and Kate B. Moore (recorder), "Dialectic: The Aims of Institutional Repositories."

The Serials Librarian 72, no. 1-4 (2017): 31.

${ }^{13}$ The material in this section is largely drawn from my own experiences working on digital library projects, managing digital assets, and overseeing an institutional repository, each at a different University. The phases of Preproduction, Production, and Post-production are often used in breaking down video and other media creation projects. I suggest these three broad stages because they allow for flexibility; as Zhang and Gourley note in Creating Digital Collections: A Practical Guide, "the best practices for managing a digitisation project depend on the scale, various stakeholders, available sources and other factors that vary from project to project.” [p. 8]
} 
of the number of items that will be added and at what frequency if it is a serial or other type of continuing collection. Size and scope are great influencers on the resulting time commitment, as a large collection may take months or years to complete. Establish a timeline for the project; is there a deadline for completion that might require it to be prioritized over other projects? Preproduction is the phase in which to make decisions about file naming conventions, where the files will be stored outside the repository (such as a secure shared drive), what file type to upload to the system, and if the upload will be performed in batches or item-by-item. Decide what metadata fields and conventions to use, and if there is existing metadata to consider using, what format or schema is it in, and can it be efficiently re-purposed for the repository? Or does metadata need to be created from scratch?. If the project involves reformatting print material, decisions should be made in this phase regarding specifications for the files being created (size, format, naming); in particular, will there be high-resolution files created and retained as "master" files, which will then copied and reduced to a smaller size for uploading to the repository? Access levels for the collection should also be discussed at this stage. While the goal of including content in an open-access online repository is to make it discoverable and available for download, many systems like Digital Commons allow for some level of access control. For example, students who deposit theses and dissertations in ISU ReD have several access options: 1.) making their full text openly available immediately upon deposit, 2.) making the metadata available but placing an embargo on the full text for a defined time period, or 3.) making the metadata available but restricting full-text downloads to only members of the Illinois State community. It is in this phase that project team members should be finalized, and their roles and responsibilities defined. When collaborating with campus stakeholders outside the library, the library may want to consider developing a memorandum of understanding (MOU) that outlines expectations for the departments/offices involved in the project and documents some of the decisions made in the pre-production phase. The MOU would be signed by an authority from each office. Finally, this phase is a good opportunity to plan for the desired appearance of the online collection. Depending on the system used, you may have very little or a great deal of flexibility in designing the user interface for each collection. Digital Commons offers different structure types that administrators can choose from when creating collections: a series (good for text-heavy files like articles and the majority of dissertations); a book gallery, which can display thumbnail and larger images that represent an item; and an image gallery, which displays images and metadata that can be viewed individually and also added to an auto-advancing image carousel. For a collection in Digital Commons, it is important to decide on the structure before content is added, so that is why this decision is ideally made before production begins.

The Production phase is when scanning and file processing (naming, saving to designated location, copying, text recognition, compression) take place. It is also the phase in which files are uploaded to and described in the repository. If someone other than the repository or project manager - such as a library student worker - is scanning, processing, and uploading files, the files should be held in a queue in the repository for review by the manager, who can approve and publish them when production work is complete. Quality control is an important part of this phase, as catching issues before the project is live and publicized both saves time making corrections later, and potentially saves the library some embarrassment, however small. It is 
helpful to document project progress in this phase; I have had success using a cloud-based spreadsheet or document that can be shared and edited by all project stakeholders.

The Post-production phase involves reviewing and publishing the collection to the repository, as well as ensuring the files and any batch metadata records are archived on a secure University server. Perhaps the bulk of this phase, however, is promotion of the completed collection to content providers and other target audiences. In addition to sharing a link to the collection on the library's website, social media channels, and University News service, a short writeup about the collection - perhaps including a quote from a content provider — can provide great value to publicizing the collection. Finally, observing and sharing usage data of a collection can help communicate the value of investing in adding the items to the repository. In the case of Digital Commons, the repository administrator can quickly and easily create usage reports that show numbers such as items uploaded, items downloaded, and metadata page views over a certain period of time. The system also automatically generates and sends monthly usage reports to stakeholders whose e-mail addresses are tied to the collection in the system.

\section{Selected ISU ReD Collections}

School of Music Programs ${ }^{14}$

This collection features historic and recent recital and ensemble programs of performances by School of Music faculty, students, and guest artists. With nearly 3,900 programs from 1966 to 2019 to date, the programs chronicle a rich history of performances in the School of Music, which typically puts on over 100 recitals and concerts each academic year. Since the collection was created in January 2018, programs included in it have been downloaded over 27,000 times.

The programs can also tell a story beyond the performances themselves. For example, the School of Music had a long relationship with American composer David Maslanka, from the early 1990s until his death in 2017. The Wind Symphony commissioned and premiered four Maslanka Symphonies. School of Music faculty and student ensembles have recorded 18 albums with Albany Records that feature Dr. Maslanka's compositions, and two pieces by Dr. Maslanka were commissioned for and premiered at the University's sesquicentennial celebrations in 2007. The School of Music honored Dr. Maslanka with a tribute concert in November 2017. Programs from these concerts are included in this collection in ISU ReD.

Pre-production: The most recent ten years of programs in this collection were provided in electronic format by the assistant dean in the Wonsook Kim College of Fine Arts. As this is an ongoing project, she continues to send these files to me directly once each academic year, and a library student worker processes the items and adds them to the collection. Because School of 
Music performances will continue each year, the collection has no completion date, meaning the timeline is flexible and the addition of this content is less urgent than others.

Production: Programs from 2009 forward were provided to us as Word DOCs and needed to be converted to PDF. Programs from 1966 to 2008 needed to be digitized. I worked with colleagues in University Archives to borrow the programs they hold and created documentation for the library student worker to complete digitization and description tasks. When scanning the programs, he created high resolution PDFs to keep as master files. During file processing, he cropped, OCRed, and reduced the file size to create access files (which load more quickly in a web browser), which were uploaded to the repository. Because of the large number of files in this collection, the files and metadata were uploaded to the system as a batch. This process involved entering metadata into an XLSX file, including a path pointing to each PDF, all of which were placed on an open server that allowed Digital Commons to access them for upload.

Post-production: The initial batch of files added to this collection numbered in the thousands, subsequent and future batches were and will be in the hundreds. So reviewing the batch metadata file and individual PDFs prior to publishing them online is a time-consuming process. Promotion of this collection to date has been minimal, but there are ever-present opportunities for featuring a particular program, performer, or ensemble through social media or particular audiences, like School of Music alumni.

\section{Red Note New Music Festival ${ }^{15}$}

Now in its twelfth season, the Red Note New Music Festival at Illinois State University is a week-long event that features performances of contemporary concert music. Typically, the festival invites one or two chamber ensembles that specialize in performing new music. Each Festival also brings to campus one or two recognized contemporary composers whose works are performed by School of Music faculty and Illinois State University student music ensembles during the festival. The festival includes a composition competition that calls for entries of works written after the year 2000. Another feature of the Festival is a composition workshop that is led by Illinois State music composition faculty and that year's guest composers. Workshop students apply to participate and those who are accepted are asked to write an original composition specifically for one of the guest ensembles appearing at that year's festival. Featured ensembles from past seasons include the Orchid Ensemble, Fulcrum Point New Music Ensemble, Color Field Ensemble, Spektral Quartet, Ensemble Dal Niente, Momenta Quartet, the City of Tomorrow, Ensemble Mise-En, Del Sol Quartet, and loadbang. Past guest composers include William Bolcom, Stephen Hartke, Sydney Hodkinson, Lee Hyla, Steven Stucky, Augusta Read Thomas, and Joan Tower. The 2019 festival featured guest composers Chen Yi and Eric Moe, as well as featured guest ensembles Fifth House Ensemble and Iridium Quartet. The 2020, the 
festival hosted composers Stacy Garrop and David Rakowski, along with NOW Ensemble and Transient Canvas.

The Red Note collection in ISU ReD features all available publications related to the festival aside from the compositions themselves, from its start in 2011 to current. Among these materials is a detailed program booklet detailing the week's performances, program notes for performed pieces, and biographies of involved artists. The collection also features copies of full-color posters and announcements for the composer workshop and competition.

Pre-production: This collection was created in collaboration with one of the composition faculty who coordinates the festival. A related effort to archive printed copies of these materials has happened alongside creation of the digital collection; most of the printed programs and other items were being kept in a filing cabinet in the faculty member's office. Those materials have been transferred to University Archives for storage and greater access. Since this collection is small and straightforward, I maintain it on my own without the help of the library student worker.

Production: All materials in this collection originated as digital files so no reformatting was necessary, though for some files it was necessary to recognize the text before uploading the PDFs to Digital Commons.

Post-production: The initial group of files I received from the faculty member covered 2011 to 2017. With only two to three files representing each year, it seemed more efficient to upload the files individually as opposed to in a batch. He continues to send me PDF copies of programs, posters, and other files after each year's festival takes place. Because this collection mostly duplicates content that is available on the festival's website and serves as a permanent archive of the festival events after they have passed each year, it does not seem to beg for promotion. But perhaps we will work with the collaborating faculty to feature it in a University News story at some point.

\section{Illinois Shakespeare Festival Programs ${ }^{16}$}

The Illinois Shakespeare Festival is an annual summer series that has been coordinated by Illinois State University's School of Theatre and Dance since 1978. The Festival is held at Ewing Manor Cultural Center, a historic estate that was gifted to the University in the late 1960s. The estate includes a 430-seat theatre with a thrust stage that is the current venue of the Festival. Approximately 10,000 people attend the Illinois Shakespeare Festival each summer. Generally, three plays are produced each year. As of the 2018 season, the company has produced all but two of Shakespeare's plays and has staged a total of 124 productions. The acting company is made up of professional actors along with some interns and current Illinois State University students. Some past company members have enjoyed successful acting careers including ISU 
School of Theatre alums Gary Cole and Tom Irwin, who became members of Chicago's famed Steppenwolf Theatre and have also appeared in numerous feature films, television movies, and series.

Pre-production: The collection currently features programs from 1980 to 2016. While University Archives has copies of festival programs, the Wonsook Kim College of Fine Arts also maintains a collection of programs and - thanks to the coordination of the assistant deanprovided digitization of the physical items for this project. Files were sent to me in batches using the University's FTP transfer service. In this case, the content provider's willingness to digitize the programs helped free up time for library staff to work on other projects. The programs feature headshots of actors and pre-production photographs, and there was some discussion among the library and fine arts administrators regarding whether the actors' contracts with the festival would permit these to be posted online. This question was resolved by the assistant dean in the Wonsook Kim College of Fine Arts, who contacted a union representative and received permission to post the programs in ISU ReD.

Production: The library student worker processed, uploaded, and entered metadata for the files. The original print programs are booklets and were scanned as "two-up," or two portrait pages side-by-side, and therefore they required more attention while processing. In addition to recognizing the text, he spent significant time cropping and reordering pages so they appeared "one-up," which would give the user a more consistent reading experience.

Post-production: With a devoted audience and an annual production cycle for the festival, we had a clear motivation for publicizing this particular collection. The university archivist wrote a news story, which was published right before the 2019 season began. ${ }^{17}$ Usage statistics show a slight increase of programs downloaded that month (61, up from 41 the previous month) but the highest number of programs downloaded in a month to date (226) was later, in November 2019.

\section{Conclusion}

While processes, workflows, and technology are all critical components when creating a collection in an institutional repository, the relationships among stakeholders are the true engine of each project. The three projects discussed above emerged from an existing connection between librarians and an academic unit and were completed with mutual goals of preserving and promoting the work of faculty, students, and staff in the fine and performing arts. I hope this piece has conveyed the sense that a successful repository project involves the work of many dedicated team members, inside the library and beyond. In my experience, it is impossible for a project manager to progress on and complete a project without a dedicated team of collaborators. The teamwork among personnel in Milner Library and the Wonsook College of Fine Arts has proved to be a fruitful arrangement that benefits both colleges.

${ }^{17}$ https://news.illinoisstate.edu/2019/06/historic-illinois-shakespeare-festival-programs-now-online/ 


\section{Bibliography}

Aufderheide, Patricia, Peter Jaszi, Bryan Bello, and Tijana Milosevic. "Copyright, Permissions, and Fair Use among Visual Artists and the Academic and Museum Visual Arts Communities: An Issues Report.” Accessed May 29, 2020, https://www.collegeart.org/pdf/FairUseIssuesReport.pdf.

Burress, Theresa, and Chelcie Juliet Rowell. "Project Management for Digital Projects with Collaborators Beyond the Library." College \& Undergraduate Libraries 24, no. 2-4 (2017): 300-21. https://doi.org/10.1080/10691316.2017.1336954.

Crow, Raym. “The Case for Institutional Repositories: A SPARC Position Paper." Washington, D.C.: Scholarly Publishing \& Academic Resources Coalition, 2002. Accessed February 10, 2020, https://ils.unc.edu/courses/2014_fall/inls690_109/Readings/Crow2002CaseforInstitutionalRepositoriesSPARCPaper.pdf.

Cullen, Rowena, and Brenda Chawner. "Institutional Repositories: Assessing Their Value to the Academic Community." Performance Measurement and Metrics 11, no. 2 (2010): 131147.

Davis, Philip M., and Matthew J. L. Connolly. "Institutional Repositories: Evaluating the Reasons for Non-use of Cornell University's Installation of DSpace.” D-Lib Magazine 13, no. 3/4 (2007). Accessed May 29, 2020, http://www.dlib.org/dlib/march07/davis/03davis.html.

Harley, Diane, Sophia Krzys Acord, Sarah Earl-Novell, Shannon Lawrence, and C. Judson King. "Assessing the Future of Landscape of Scholarly Communication: An Exploration of Faculty Values and Needs in Seven Disciplines." Berkeley, CA: The Center for Studies in Higher Education, 2010. Accessed May 29, 2020, https://escholarship.org/uc/item/15x7385g\#.

Kelly, Kristin. "Images of Works of Art in Museum Collections: The Experience of Open Access. A Study of 11 Museums.” CLIR Publication No. 157. Washington, D.C.: Council on Library and Information Resources, 2013. Accessed May 29, 2020, https://www.clir.org/pubs/reports/pub157/

Lambaria, Kate. "Considering Creative Activity in Institutional Repositories: An Exploration of Faculty Perceptions." Journal of Librarianship and Scholarly Communication 8, no. 1 (2020): p.eP2312. DOI: http://doi.org/10.7710/2162-3309.2312.

Lynch, Clifford. "Institutional Repositories: Essential Infrastructure for Scholarship in the Digital Age." ARL Bimonthly Report 226 (February 2003): 1-7. Accessed February 10, 2020, https://www.cni.org/wp-content/uploads/2003/02/arl-br-226-Lynch-IRs-2003.pdf.

Meece, Stephanie, Amy Robinson, and Marie-Therese Gramstadt. "Engaging Researchers with the World's First Scholarly Arts Repositories: Ten Years After the UK's Kultur Project." 
New Review of Academic Librarianship 23, nos. 2-3 (2017): 209-232.

https://doi.org/10.1080/13614533.2017.1320767.

Milner Library, Illinois State University. "ISU ReD: Research and eData." Accessed February 10, 2020, https://ir.library.illinoisstate.edu/.

Plutchak, T. Scott (speaker), and Kate B. Moore (recorder). "Dialectic: The Aims of Institutional Repositories.” The Serials Librarian 72, no. 1-4 (2017): 27-35. DOI: 10.1080/0361526X.2017.1320868.

Poynder, Richard. "Q\&A with CNI's Clifford Lynch: Time to Re-think the Institutional Repository?" Last modified September 22, 2016. https://richardpoynder.co.uk/Clifford_Lynch.pdf.

Rieh, Soo Young, Karen Markey, Elizabeth Yakel, Beth St. Jean, and Jihyun Kim. "Perceived Values and Benefits of Institutional Repositories: A Perspective of Digital Curation." Paper presented at DigCCurr 2007: An International Symposium in Digital Curation, Chapel Hill, NC, April 2007. https://ils.unc.edu/digccurr2007/program.html. 